\title{
O DEVER DE INDENIZAR O TEMPO DESPERDIÇADO (DESVIO PRODUTIVO)
}

\author{
THE DUTY TO COMPENSATE THE WASTED TIME (PRODUCTIVE DEVIATION)
}

\author{
Tarcisio Teixeira* \\ Leonardo Silva Augusto**
}

\begin{abstract}
Resumo:
O presente artigo tem por finalidade realizar uma abordagem acerca do dever de indenizar o tempo desperdiçado nas relações de consumo, ou, como usualmente tem se denominado, a responsabilidade civil pela perda do tempo útil, ou, ainda, o 'desvio produtivo do consumidor'. Verificamos se o tempo, além de tratar-se de um importante bem, é, também, um bem jurídico, ou seja, se é protegido pelo ordenamento jurídico pátrio. Em outras palavras, se é merecedor de tutela, ensejando ao causador de eventual lesão o dever de indenizar o tempo desperdiçado. $\mathrm{Na}$ sequência, realizamos um estudo sobre a tese "Desvio Produtivo do Consumidor". Ainda, a partir da análise de julgados, verificaremos a adoção da teoria da 'responsabilidade civil pela perda do tempo útil' por diversos Tribunais de Justiça, o que tem levado à condenações por dano moral em razão da perda do tempo útil do consumidor. E, por fim, tendo em vista a constatação da importância do tempo, uma vez tratar-se de um bem escasso, inacumulável, irrecuperável, e considerando a possibilidade de tutela jurídica, verifica-se a necessidade do reconhecimento de uma nova modalidade de dano, qual seja, o dano temporal.
\end{abstract}

Palavras-chave: Dever de Indenizar. Perda do Tempo. Tempo Desperdiçado. Relação de Consumo.

\begin{abstract}
:
The goal of this paper is to analyze the duty of compensate the wasted time in consumer relationships, or, as usually stated, liability for loss of lifetime, or even, consumer's productive deviation. This work studies if time, besides being an important asset, is also a legal interest, that is whether protected by the Brazilian legal system. In other words, if time deserves special care, then it's loss must be compensated. Following, the thesis "productive consumer deviation" is studied. Moreover, based on case-law analysis, the liability for loss of productive time thesis is verified as to be adopted in many courts, which has led to moral damage lawsuits based on loss of productive time. Finally, considering the importance of time as a rare, non-recoverable, non-accumulating asset, and considering the possibility of care by law, the need for a new modality of damage, namely temporal damage, is verified.
\end{abstract}

\footnotetext{
Mestre e Doutor em Direito Comercial pela Faculdade de Direito da Universidade de São Paulo. Professor de Direito Empresarial da Universidade Estadual de Londrina - UEL. Autor, entre outras obras, de: Curso de direito e processo eletrônico e Direito empresarial sistematizado. Contato: tarcisioteixeira@tarcisioteixeira. com.br.

** Graduado em Direito pela Universidade Estadual de Londrina (UEL). Pós-graduando em Direito Penal pela Universidade Estadual de Londrina. Advogado. Contato: leonardosaugusto@gmail.com.
} 
Keywords: Duty of Compensation. Lost Time. Wasted Time. Consumer Relationship.

Introdução

Aguardar demasiadamente por atendimento na fila do banco; ficar perdurado na linha telefônica por horas tentando cancelar o serviço de "TV por assinatura" contratado; tentar inúmeras vezes, porém sem sucesso, reaver o valor cobrado indevidamente na conta telefônica; esperar por mais de dois meses o conserto do produto recém adquirido e, ainda, ver negado o pedido de troca por outro ou a devolução da quantia paga. Estas, e tantas outras, são intoleráveis situações vivenciadas cotidianamente por milhares de consumidores no nosso país e que acarretam em um inestimável prejuízo: a perda do tempo.

Tempo este que, dentre outras coisas, poderia ser destinado ao convívio familiar, ao trabalho, ao descanso, ao lazer, ao ócio. Entretanto, os consumidores, nas situações de mau atendimento a que são submetidos diariamente, são obrigados involuntariamente a desviar este precioso tempo das atividades por eles desejadas, desperdiçando-o na solução dos problemas causados pelos fornecedores, suportando um dano malquisto, denominado usualmente de dano temporal, perda do tempo ou desvio produtivo do consumidor.

Em que pese tratar-se de um inequívoco e inestimável prejuízo, doutrina e jurisprudência, de maneira geral, ainda resistem em reconhecer a ressarcibilidade do dano temporal, considerando tratar-se de 'mero dissabor' e 'aborrecimento inevitável' o tempo desperdiçado pelos consumidores nas situações ilustradas alhures.

Diante de tais circunstâncias, o presente trabalho tem por escopo estudar a possibilidade de reconhecimento, pela jurisprudência e doutrina, deste novo dano temporal suportado por inúmeros consumidores brasileiros e seu consequente ressarcimento.

1. Do tempo

1.1. Aspectos gerais

A "teoria do dever de indenizar o tempo desperdiçado", como o próprio nome aduz, tem por fundamento o tempo. Mais do que isso, o tempo desperdiçado. Não se trata aqui, entretanto, de mero desperdício de tempo, mas de um desperdício de tempo injusto e intolerável.

Desta feita, sendo o tempo o elemento informador da disciplina objeto do presente trabalho, emerge uma indagação que certamente, seja nas rodas de debate entre 
amigos, seja nos minutos de reflexão que precedem o sono, já fora realizada por todos: o que é tempo?

O tempo, aliás, ocupa o imaginário do ser humano há milênios, desde a Idade Antiga até a contemporaneidade. Na mitologia grega, por exemplo, havia o Deus Chronos, o deus do tempo, que, segundo a lenda, devorava seus próprios filhos, numa alusão clara à ideia de que tudo será consumido pelo tempo. ${ }^{1}$

Nos tempos atuais, quem não se recorda do filme norte-americano, lançado em 1985, "De volta para o futuro" (Back to the future), do diretor Robert Zemeckis. No filme, um jovem aciona acidentalmente uma máquina do tempo construída por um cientista e acaba retornando aos anos de 1955. Na oportunidade, o jovem acaba por conhecer sua própria mãe, a qual se apaixona por ele. Temendo alterar todo o futuro, condenando até mesmo sua própria existência, o jovem passa a procurar pelo cientista, criador da máquina, com intuito de voltar ao ano de 1985, ou seja, voltar ao futuro.

Estes são, portanto, meros exemplos de como o ser humano, independentemente da época, se fascinou pelo tema tempo, ora 'criando' máquinas que pudessem nos remeter ao passado, ora interrompendo o próprio fluxo do tempo.

$\mathrm{Na}$ mesma proporção que surgiram histórias fantasiosas relativamente ao tempo, também surgiram inúmeras conceituações de tempo. Nicola Abbagnano aponta a existência de três concepções principais, quais sejam (i) o tempo como ordem mensurável do movimento, (ii) o tempo como movimento intuído e (iii) o tempo como estrutura de possibilidades. $^{2}$

A primeira concepção de tempo é a mais antiga e difundida, estando associada, na Antiguidade, ao conceito cíclico do mundo e da vida do homem e, na época moderna, ao conceito científico de tempo. O conceito de Aristóteles de que "o tempo é o número do movimento segundo o antes e o depois" resume com perfeição a noção de tempo como a ordem mensurável do movimento.

Importante contribuição para a concepção do tempo como ordem mensurável do movimento foi dada por Immanuel Kant, ao reduzir o tempo à ordem causal, afirmando que uma coisa só "pode conquistar seu lugar no tempo com a condição de que no estado precedente se pressuponha outra coisa à qual esta sempre deva seguir-se, ou seja, segundo uma regra". E continua: "uma vez posto o estado precedente, o acontecimento deve seguir-se infalível e necessariamente".

Em relação à segunda concepção, o tempo mantém íntima relação com a consciência. Para Santo Agostinho, o tempo é identificado com a própria vida da alma que

KURY, Mário da Gama. Dicionário de mitologia. 5. ed. Rio de Janeiro: Jorge Zahar Editor, 1999. p. 96.

2 ABBAGnANO, Nicola. Dicionário de filosofia. Trad. Ivone Castilho Benedetti e Alfredo Bosi. 4. ed. São Paulo: Martins Fontes, 2003. p. 944. 
se estende para o passado ou para o futuro. Ainda, de acordo com o filósofo, "a rigor, não existem três tempos, passado presente e futuro, mas somente três presentes: o presente do passado, o presente do presente e o presente do futuro".

Já quanto à terceira concepção, a qual concebe o tempo como estrutura de possibilidades, temos na filosofia existencialista de Heidegger a principal influência. De acordo com Abbagnano, "Heidegger, (...), interpretou o tempo em termos de possibilidade ou de projeção: o tempo é originariamente o por-vir...”. Ainda, segundo Abbagnano, para a teoria heideggeriana o "tempo é considerado uma espécie de círculo, em que a perspectiva para o futuro é aquilo que já passou; por sua vez, o que já passou é a perspectiva para o futuro". 3

André Comte-Sponville, em seu 'Dicionário Filosófico', assinala duas acepções de tempo: tempo abstrato (aión) e tempo concreto ou real (khrónos). Segundo o autor, é comum a confusão entre estas duas acepções, entretanto, é essa confusão que geralmente chamamos de tempo. Na lição do autor, "o tempo é, ante de mais nada, a duração, mas considerada independente do que dura, ou seja, abstratamente. Não um ser, portanto, mas um pensamento". "É", continua o autor, "como que a continuação indefinida e indeterminada de uma existência: o que ainda continuaria, em todo o caso é nossa sensação, se mais nada existisse".

Ainda, pondera Comte-Sponville, "esse tempo abstrato [...] pode ser concebido, e costuma sê-lo, como a soma do passado, do presente e do futuro". E segue lecionando: "considerado abstratamente, o tempo é constituído essencialmente de passado e futuro (o que o presente nunca é) e mensurável (o que o presente também não é). É o tempo dos cientistas e dos relógios".

Já o tempo em sua acepção concreta ou real, nas palavras do ComteSponville, "é a duração de tudo, em outras palavras, a continuação indefinida do universo, que permanece sempre o mesmo, $[. .$.$] , muito embora não cesse de mudar de uma infinidade$ de maneiras".

"É o tempo da natureza ou do ser: o devir em via de devir, a mudança contínua dos entes. O passado? Não é nada real, pois já não é. O futuro? Não é nada real, pois ainda não é. Na natureza, só há o presente".

E arremata o autor afirmando que "O tempo, em sua verdade, é portanto o tempo da natureza: nada mais é que um perpétuo, embora múltiplo e mutável, agora. É por isso que se confunde com a eternidade". ${ }^{4}$

ABBAGNANO, Nicola. Dicionário de filosofia, cit., p. 944-948.

4 COMTE-SPONVILlE, André. Dicionário filosófico. Trad. Eduardo Brandão. São Paulo: Martins Fontes, 2003. p. 586-587. 
Interessantes são as considerações a respeito do 'tempo livre' do sociólogo italiano Domenico De Masi, trazidas por Marcos Dessaune, em sua obra "Desvio Produtivo do Consumidor". ${ }^{5}$ De acordo com o autor, para De Masi, "tempo livre significa viagem, cultura, erotismo, estética, repouso, esporte, [...] Significa, antes de tudo, nos exercitarmos em descobrir quantas coisas podemos fazer, desde hoje, no nosso tempo disponível, sem gastar um tostão". O italiano afirma: "Em suma, [tempo livre é] dar sentido às coisas de todo o dia, em geral lindas, sempre iguais e sempre diversas, que infelizmente são depreciadas pelo uso cotidiano".

É no tempo livre, destinado ao lazer, ao divertimento, à amizade, ao amor, que De Masi aponta nascer o que ele denominou "ócio criativo". Segundo o autor, "o tempo livre oferece sobretudo a possibilidade de introspecção, de jogo, de convívio, de amizade, de amor e de aventura. Não se entende por que o prazer ligado ao trabalho deveria acabar com a alegria do tempo livre". Ele provoca ao afirmar que "o trabalho é uma profissão, o ócio é uma arte" e combate, ainda, qualquer tentativa de crítica à sua teoria assinalando que "os escravos do trabalho, [...] sutilmente invejam e tenazmente combatem os 'mestres da vida' que sabem usufruir do ócio e amam apagar a distinção entre arte e vida".

Entretanto, Domenico De Masi, ao explicar a pedagogia do ócio, de como tal deve ser repassada às gerações futuras, alerta para os perigos da alienação que pode ser provocada pelo tempo vago. Desta forma, pondera o autor que "é preciso ensinar aos jovens não só como se virar nos meandros do trabalho, mas também pelos meandros dos vários possíveis lazeres". E continua: "Significa ensinar como se evita a alienação que pode ser provocada pelo tempo vago, tão perigosa quanto a alienação derivada do trabalho".

O ócio, ou 'ócio criativo' como prefere o sociólogo italiano, portanto, se consubstancia em uma ferramenta eficaz pela qual os indivíduos podem alcançar a plenitude do conhecimento e da qualidade de vida, uma vez que o tempo livre permite as pessoas se dedicarem "às atividades em que haja, simultaneamente, a criação de um valor (pelo trabalho), o aprendizado (pelo estudo) e o divertimento (pelo lazer)" ${ }^{6}$

Outro interessante conceito de tempo, também contido no livro "Desvio Produtivo do Consumidor", de autoria de Marcos Dessaune, é o formulado pela física sueca Bodil Jönsson. Segundo Jönsson, o tempo "constitui o verdadeiro capital" do homem, o maior e mais valioso capital, contrapondo a noção muito disseminada nas

5 DESSAUne, Marcos. Desvio produtivo do consumidor: prejuízo do tempo desperdiçado. São Paulo: Revista dos Tribunais, 2011. p. 90.

6 DE MASI apud DESSAUNE, Marcos. Desvio produtivo do consumidor: prejuízo do tempo desperdiçado, cit. p. 100-102. 
sociedades capitalistas de que "tempo é dinheiro", isto é, de que "o dinheiro constitui o padrão-ouro da vida”. Portanto, Bodil Jönsson leciona que o tempo, não o dinheiro, é o verdadeiro padrão-ouro da vida, pois “é o capital que possuímos passível de ser convertido em dinheiro, em relações humanas, em interação com o meio ambiente, em conhecimento, em aprofundamento de sentimentos". Desta forma, sendo o tempo o principal, maior e mais valioso capital do homem, Jönsson assinala que "não é justo nem digno, sob um ponto de vista humano, aceitar que o tempo seja transformado em um bem sempre em falta, tal como o encaramos".

Em suma, na lição de Bodil Jönsson, “o tempo vivido e pessoal é o que há de mais importante para o indivíduo", sua maior riqueza. Consequentemente, sua utilização deve se dar da maneira mais proveitosa para o indivíduo, partilhando sua destinação ora para a obtenção de dinheiro, ora para as relações pessoais, ao conhecimento, lazer, entre outros, de modo a eliminar o desperdício de tempo. ${ }^{7}$

Resumindo todos os conceitos, temos o tempo como algo inestimável, o capital maior e mais valioso do homem, sua maior riqueza (Bodil Jönsson); o 'tempo livre', de Domenico De Masi, como fonte de lazer, introspecção, viagem, jogo, cultura, prazer, etc., enfim, como meio no qual floresce o 'ócio criativo'; o tempo como ordem mensurável do movimento (Aristóteles); o tempo, ainda, como algo finito e autêntico (Heidegger); e, por fim, o tempo como movimento intuído.

\subsection{Tempo como recurso produtivo e bem valioso da pessoa}

Como visto, o tempo, na concepção trazida por Bodil Jönsson, se constitui no capital mais valioso do ser humano, através do qual o homem produz riquezas, mantém suas relações interpessoais, adquire conhecimento, interage com o meio ambiente, sendo, ainda, um recurso produtivo escasso de que dispõe o consumidor em suas relações de troca com os fornecedores.

Esta é a constatação a que chegou o professor Marcos Dessaune. Além do tempo como recurso produtivo da pessoa, o autor identificou, ainda, a existência de outros cinco recursos disponíveis ao indivíduo quando da realização do consumo, quais sejam: recursos naturais vulneráveis, que são o ar, a água e outros bens de uso comum que tornam possível a existência da vida, no presente e no futuro; recurso cognitivo abstrativo, que é a sua consciência; recursos vitais vulneráveis, que são o seu equilíbrio psíquico e físico; recursos materiais limitados, que são seus bens e direitos e o seu montante de crédito; e, recurso volitivo condicionado, que é a sua liberdade (possibilidade de escolha).

JÖNSSON, Bodil apud DESSAUNE, Marcos. Desvio produtivo do consumidor: prejuízo do tempo desperdiçado, cit., p. 102-105. 
Aliás, ao lado do 'tempo' como recurso produtivo limitado da pessoa, identificou o autor as 'competências' como outro recurso produtivo escasso de que dispõe a pessoa nas relações de consumo. Por competência, esclarece, entende-se o "conjunto de conhecimentos ou saber, habilidades ou saber-fazer e atitudes ou saber-ser, necessário para o desempenho de uma atividade, seja ela qual for". 8

Não obstante ser valiosa a contribuição de Dessaune, ao identificar os recursos de que dispõe o consumidor nas relações de troca com o fornecedor, para a compreensão das relações de consumo, focaremos nossa análise no tempo como recurso produtivo limitado da pessoa.

O tempo, como recurso produtivo da pessoa, é limitado, escasso, conforme afirmado alhures. Tendo em vista tal peculiaridade, a fim de melhor compreender o tempo como recurso produtivo, é preciso compreender o fenômeno da escassez, o qual é amplamente estudado pelas Ciências Econômicas.

A escassez se explica, de forma simplificada, pelo fato de que os indivíduos e a sociedade possuem carências maiores do que os recursos relativamente disponíveis para satisfazê-las. Dessa forma, a fim de satisfazer o máximo de suas carências com o mínimo dispêndio de recursos, os indivíduos passam a fazer escolhas a todo momento, isto é, a escassez de recurso limita as opções e força as pessoas a escolher entre alternativas concorrentes, sempre buscando maximizar o seu bem-estar. Ao ato de escolha das possibilidades é dado o nome de 'custo de oportunidade', que é tudo aquilo a que a pessoa voluntariamente renuncia em consequência de uma decisão. A escassez está intimamente relacionada à "lei da oferta e da procura", haja vista que ela determina a dinâmica da quantidade e do preço dos bens econômicos no mercado e, dessa forma, determina o grau de escassez relativa desses bens. De acordo com os ditames de tal lei econômica, o aumento do preço de determinado produto acarreta no aumento da oferta de tal produto, uma vez que o fornecedor do produto busca a obtenção de maiores lucros. De maneira inversa, a diminuição no preço de determinado produto gera o aumento da demanda de tal produto, haja vista que o consumidor busca maximizar seu bem-estar. ${ }^{9}$

Sendo assim, é possível, mantendo-se outros fatores constantes, estabelecer um ponto de equilíbrio entre a oferta e a procura, em que a quantidade oferecida de certo bem é igual à quantidade demandada de tal bem, coincidindo-se, consequentemente, o preço almejado pelo fornecedor e o preço que os consumidores estão dispostos a pagar pelo bem em questão.

Dessa forma, quando, relativamente a determinado produto, há uma diminuição do preço, aumenta-se a demanda por este produto, uma vez que o consumidor

DESSAUNE, Marcos. Desvio produtivo do consumidor: prejuízo do tempo desperdiçado, cit., p. 94-95.

DESSAUNE, Marcos. Desvio produtivo do consumidor: prejuízo do tempo desperdiçado, cit., p. 106-108. 
tende a maximizar seu bem-estar. $\mathrm{O}$ aumento na procura pelo produto, ao romper com o equilíbrio existente entre a oferta e a demanda, leva à escassez de tal produto, uma vez que a quantidade oferecida do bem será menor do que a quantidade demandada.

É possível concluir, portanto, que quanto maior a demanda relativa de determinado bem, mais escasso ele é e, consequentemente, mais valioso. Do contrário, quanto mais abundante é um bem no mercado, tanto menor tende a ser o seu valor.

Visto isto, relativamente ao tempo, pode-se dizer tratar-se de um recurso produtivo escasso, uma vez que o indivíduo, a fim de satisfazer plenamente suas carências, demanda uma maior quantidade de tempo do que aquela que lhe é ofertada.

Isto é, para satisfazer suas necessidades relativamente ao lazer, ao convívio familiar, ao descanso, aos trabalhos domésticos, entre outros, o indivíduo precisa de mais tempo do que aquele que lhe resta, já que grande parte de seu tempo é destinado ao trabalho, sendo que, não raras vezes, tal trabalho excede em muito a jornada ordinária de oito horas prevista constitucionalmente.

Soma-se ao tempo destinado ao trabalho, ainda, o tempo desperdiçado no trajeto casa/trabalho, o qual é agravado em grandes cidades, onde são maiores as distâncias a serem percorridas, os transportes públicos, em sua maioria, são ineficazes, e o tráfego de veículos é lento em razão da grande quantidade de carros.

Conclui-se, portanto, que as pessoas, a fim de investir principalmente em qualidade de vida, necessitam cada vez de mais tempo, sendo insuficiente a quantidade de que dispõe, consubstanciando o tempo, desta forma, em um bem verdadeiramente escasso. Além de possuir a escassez como traço característico, o tempo possui, ainda, outras tantas características, como a impossibilidade de ser tocado, de ser parado e, até mesmo, de ser revertido. A intangibilidade, a ininterruptibilidade e a irreversibilidade são características do tempo que lhe tornam inacumulável e irrecuperável, ou seja, diferentemente dos bens materiais, trata-se de um recurso que não se pode acumular, tampouco recuperar durante a vida. ${ }^{10}$

Ora, tratando-se, desta forma, de um bem intangível, ininterrupto, irreversível, inacumulável e irrecuperável, não há como não concordar com a física sueca Bodil Jönsson, citada no início deste tópico, segundo a qual o tempo é o bem mais valioso que nós, seres humanos, possuímos.

O tempo, portanto, se revela, indubitavelmente, como o bem primordial e mais valioso de que cada pessoa dispõe em sua existência terrena, comparável somente à saúde física e mental, necessária para gozá-lo plenamente.

$\overline{10}$ DESSAUNE, Marcos. Desvio produtivo do consumidor: prejuízo do tempo desperdiçado, cit., p. 108. 


\subsection{Tempo como bem jurídico}

O homem em sociedade tende a valorizar aquilo que satisfaça as suas necessidades, que lhe seja útil, que realize os seus desejos, que seja escasso na natureza.

Conforme ensinamentos de Paulo Nader, "o homem atribuí valor às coisas, na medida em que, por suas propriedades, satisfaçam aos seus interesses". E, conclui o filósofo do direito afirmando que "a ação humana é a busca permanente do positivamente valioso, do que atende às necessidades do ser racional". Neste sentido, portanto, o homem, ao se deparar com determinado objeto, elabora juízo de valor em relação a tal, atribuindolhe valor, positivo ou negativo, de acordo com as propriedades ou qualidades oferecidas pelo objeto, bem como relativamente à satisfação de suas próprias necessidades ou carências.

A noção de valor está intimamente relacionada ao Direito, podendo-se afirmar que o valor é um de seus componentes básicos. O Direito, por não ser produto espontâneo da natureza, mas sim uma criação humana, é considerado objeto cultural, e, como objeto cultural, realiza valores. Tal se dá, por exemplo, quando uma lei proíbe determinada conduta, uma vez que emitirá juízo de reprovação relativamente à tal conduta. De igual forma, quando a lei impõe a realização de determinada conduta julgada necessária, também se está realizando valores, porém, neste caso, um juízo de aprovação.

No entanto, o Direito não apenas realiza valor, mas, também, dispõe sobre valores. Ao disciplinar o convívio social, o Direito procura exercer a proteção de bens relevantes para o homem, como a vida, a liberdade, o patrimônio, entre outros. É via as normas que o Direito, a partir de um complexo de valoração, efetiva a proteção daquilo que possui significado para o ser racional. Neste sentido, é possível afirmar que a função social do Direito é conferir valores aos fatos da vida, aos diversos interesses subjacentes e aos bens, regulando sua distribuição entre as pessoas. ${ }^{11}$

Em outras palavras, a valorização e a procura pelos indivíduos por determinada coisa torna esta coisa em um bem. Consequentemente, em razão de sua grande valia, surge o interesse em tutelar tal bem. A tutela deste bem surge com sua normatização, e, protegido pela legalidade, tal bem é elevado ao patamar de bem jurídico.

Com efeito, entende-se como sendo um bem tudo aquilo que nos apresenta como valioso, necessário, útil, digno, isto é, em um contexto de valoração pessoal, deve ser considerado como bem aquilo que satisfaça as necessidades do ser humano, que lhe preste utilidade, que possua elevada importância. Em suma, os bens são, pois, coisas ou objeto dotado de 'valor', ou seja, coisas ou objetos que além de ser o que são, valem. ${ }^{12}$

11 NADER, Paulo. Filosofia do direito. 15. ed. Rio de Janeiro: Forense, 2006. p. 52-54.

12 ALLEGRO, Romana Affonso de Almeida. Bens jurídicos: o interesse estatal de tutelar bens jurídicos através 
Importante ressaltar que na noção de bem estão inseridos tanto os objetos físicos como qualidade de uma pessoa, tanto direitos quanto garantias, materiais e imateriais, interesses e objetos vinculados por um conceito de valores sociais, que os destaca como de grande ou significante valia. ${ }^{13}$

Bem é, portanto, tudo aquilo que é útil, que satisfaça uma necessidade ou carência, que é digno. Em síntese, é aquilo que possui valor, importância para o ser humano. Porém, para que um bem passe a ser considerado como um bem jurídico é necessária, conforme assentado acima, sua normatização.

Embora a noção de bem jurídico permeie toda a estrutura do Direito, é no Direito Penal que encontraremos o melhor entendimento acerca do conceito de bem jurídico, haja vista que uma das funções do Direito Penal é a proteção de bens ou interesses juridicamente tutelados.

Sendo assim, segundo Claudio José Langroiva Pereira, em sua obra Proteção Jurídico-Penal e Direitos Universais, entende-se por bem jurídico como sendo "um valor ideal, proveniente da ordem social em vigor, juridicamente estabelecido e protegido, em relação ao qual a sociedade tem interesse na segurança e manutenção". ${ }^{14}$

No mesmo sentido, Aníbal Bruno destaca que os bens jurídicos "são valores de vida individual ou coletiva, valores da cultura". ${ }^{15}$ Para Assis Toledo, bens jurídicos "são valores ético-sociais que o direito seleciona, com o objetivo de assegurar a paz social, e coloca sob sua proteção para que não sejam expostos a perigo de ataque ou a lesões efetivas". ${ }^{16}$ Seguindo a mesma linha de pensamento, Fragoso assevera que "bem jurídico é um bem protegido pelo direito: é, portanto, um valor da vida humana que o direito reconhece, e a cuja preservação é disposta a norma". ${ }^{17}$

Em síntese, a noção de bem jurídico está estreitamente ligada à noção de valor. Este, por sua vez, decorre das necessidades do homem surgidas na experiência concreta da vida, ou seja, somente se atribui valor a alguma coisa na medida em que esta pode satisfazer uma necessidade humana, isto porque a necessidade gera valor. ${ }^{18}$

Por todo o exposto, seria possível afirmar ser o tempo um bem jurídico?

de sua normatização. Disponível em: <http:/www.diretonet.com.br/artigos/exibir/2089/Bens-juridicos>. Acesso em: 3 mar. 2015.

13 PEREIRA, Carlos José Langroiva. Proteção jurídico-penal e direitos universais: tipo, tipicidade e bem jurídico universal. São Paulo: Quartier Latin, 2008. p. 71.

14 Id. Ibid., p. 72.

15 BRUNO, Aníbal apud PRADO, Luiz Régis. Bem jurídico penal e constituição. 3. ed. São Paulo: Revista dos Tribunais, 2003. p. 48.

16 TOLEDO, Assis apud PRADO, Luiz Régis. Bem jurídico penal e constituição, cit., p. 50.

17 FRAGOSO, Heleno Cláudio apud PRADO, Luiz Régis. Bem jurídico penal e constituição, cit., p. 51.

18 PRADO, Luiz Régis. Bem jurídico penal e constituição, cit., 49. 
Conforme visto, por se tratar de um bem que não se pode tocar, não se pode parar, tampouco reverter; impossível, além, de se acumular e de se recuperar; por se tratar, ainda, de um recurso produtivo escasso, o tempo, inequivocamente, se revela como o bem mais valioso de que a pessoa dispõe em sua vida.

Marcos Dessaune, em sua já citada obra Desvio produtivo do consumidor, aponta o tempo, ao lado das competências (conjunto de conhecimentos ou saber, habilidades ou saber-fazer e atitudes ou saber-ser), como um dos recursos produtivos escassos de que dispõe o consumidor em suas 'relações de troca' com o fornecedor. ${ }^{19}$

Para Bodil Jönsson, ${ }^{20}$ citada alhures, o tempo é o verdadeiro capital do homem, o padrão-ouro da vida, haja vista que o tempo é o meio pelo qual os homens auferem riquezas, estabelecem relações sociais, interagem com o meio ambiente, adquirem conhecimento, aprofundam os sentimentos. Ou seja, trata-se do maior e mais valioso capital do homem.

Ainda, segundo Domenico De Masi, ${ }^{21}$ o tempo livre possibilita ao ser humano realizar o que ele denominou de 'ócio criativo', isto é, o tempo livre oferece a possibilidade ao indivíduo de introspecção, de jogo, de convívio, de amizade, de amor e de aventura. O ócio criativo significa, em suma, dar sentido às coisas de todo o dia, em geral lindas, sempre iguais e sempre diversas, que infelizmente são depreciadas pelo uso cotidiano.

No entanto, não é simplesmente por se tratar no capital mais valioso do ser humano, segundo Jönsson, ou no meio pelo qual floresce o ócio criativo, de acordo com De Masi, ou, então, por ser um recurso produtivo escasso do consumidor, conforme Dessaune, ou, ainda, por ser algo inacumulável, irrecuperável, intangível entre outros, que o tempo possui a condição de bem jurídico.

Ante as características listadas, conclui-se facilmente tratar-se o tempo em um bem. Por obséquio, um bem escasso e mais valioso de que dispõe a pessoa. Contudo, a fim de ser elevado à categoria de bem jurídico, é preciso que o bem 'tempo' seja tutelado juridicamente, isto é, com sua normatização, seja coberto pelo manto protetor da legalidade.

Neste sentindo, ainda que de forma acanhada e bem aquém da sua importância em nossas vidas, a Constituição Federal de 1988 faz referência ao tempo em alguns poucos dispositivos, dentre eles os incisos XIII, XIV, XV e XVII do art. $7^{\circ}$,

19 DESSAUNE, Marcos. Desvio produtivo do consumidor: prejuízo do tempo desperdiçado, cit., p. 93.

20 JÖNSSON apud DESSAUNE, Marcos. Desvio produtivo do consumidor: prejuízo do tempo desperdiçado, cit., p. 105.

21 DE MASI apud DESSAUNE, Marcos. Desvio produtivo do consumidor: prejuízo do tempo desperdiçado, cit., p. 102. 
que tratam da duração do trabalho e dos períodos de descanso do trabalhador, bem com o inciso LXXVIII do art. $5^{\circ}$, o qual garante ao cidadão a razoável duração do processo.

Ademais, ainda que de modo indireto ou mediato, é possível verificar, a partir de uma interpretação sistemática da Carta Maior, a referência ao tempo como suporte implícito do direito constitucional ao lazer e do estudo, sendo este considerado como modo de aquisição do conhecimento, que é objeto do direito constitucional à educação.

No entanto, segundo Dessaune, não obstante as referências, diretas ou indiretas, encontradas no corpo da Constituição relativamente ao tempo, não é possível afirmar ser o tempo um bem jurídico, isto é, ser o tempo objeto de direitos.

Para o autor, é preciso identificar se o tempo, conforme resta tratado na Constituição Federal, é bem jurídico, ou seja, objeto de direitos, ou é direito constitucional em todas ou algumas situações específicas. Isto porque, continua Dessaune, "há diferença na hipótese de ocorrer uma violação do tempo como direito subjetivo constitucional da pessoa-consumidora, em comparação com uma lesão do tempo como bem jurídico constitucional". Tal distinção se imporia, em tese, uma vez que, se verificada a ocorrência de uma violação do tempo como direito subjetivo constitucional do consumidor, tal violação se consubstanciaria em simples "ato ilícito". Em contrapartida, se considerado o tempo como bem jurídico constitucional, eventual lesão se configuraria de fato em algum "dano", gerando para o causador de tal dano o dever de repará-lo.

Nestes termos, quando a Constituição Federal dispõe acerca da duração do trabalho e dos períodos de descanso do trabalhador, ou quando assegura ao cidadão a razoável duração do processo, ou, então, quando aponta o tempo como suporte implícito ao direito ao lazer e ao estudo como modo de aquisição do objeto do direito constitucional à educação, estaria a Carta Política consagrando o tempo como bem jurídico autônomo?

A depender do entendimento de Marcos Dessaune, a resposta é 'não'. De acordo com o autor, o 'tempo útil, livre ou produtivo' do consumidor não é considerado como bem jurídico pela Constituição Federal, não havendo, consequentemente, no ordenamento jurídico pátrio, previsão relativamente às consequências fáticas danosas decorrentes de eventual violação do bem tempo. Para o autor, ao tratar da duração do trabalho e dos períodos de descanso do trabalhador, a Constituição Federal está tratando do "tempo" como direito subjetivo fundamental do trabalhador, consagrando, em verdade, 'a melhoria de sua condição social' como bem jurídico, e não o tempo em si. ${ }^{22}$

Isto porque, segundo Marcos Garcia Hoeppner, a finalidade da referida previsão constitucional é a restauração física e mental do trabalhador, sua integração e desenvolvimento socioculturais e o reconhecimento do crescimento econômico que o

22 DESSAUNE, Marcos. Desvio produtivo do consumidor: prejuízo do tempo desperdiçado, cit., p. 123-132. 
empregado proporciona à empresa e à sociedade. ${ }^{23}$ Dessaune assevera que a inobservância pelo empregador da limitação do tempo de trabalho e dos períodos de descanso acarretaria na violação do direito fundamental do trabalhador ao tempo, configurando, assim, ato ilícito. Entretanto, eventual dano resultante de tal conduta ilícita recairia sobre o bem jurídico 'melhoria da condição social do trabalhador', e não sobre o tempo de que dispõe o trabalhador em sua vida.

Relativamente à garantia a razoável duração do processo, insculpida do art. $5^{\circ}$, inciso LXXVIII, da Constituição Federal, Marcos Dessaune, amparado nos ensinamentos de Márcio Luís Dutra de Souza, para o qual, em síntese, a garantia constitucional a razoável duração do processo objetiva aumentar a efetividade na prestação jurisdicional, afirma ser a 'efetividade da prestação jurisdicional' o bem jurídico implicitamente tutelado, enquanto o ‘tempo razoável de duração dos processos' é direito subjetivo fundamental da pessoa. Conclui o autor, neste sentido, que a infração ao direito individual à razoável duração do processo caracterizaria ato ilícito, porém, o dano decorrente de tal violação incidiria, teoricamente, sobre a 'efetividade da prestação jurisdicional', considerada bem jurídico, e não sobre o direito ao tempo razoável de duração dos processos.

Quanto ao tempo como suporte implícito do direito constitucional ao lazer, Dessaune afirma que a Constituição Federal, ao elevar o lazer à categoria de direito social, conforme redação de seu art. $6^{\circ}$, e de impor ao Poder Público, em seu art. 217, $\S 3^{\circ}$, a obrigação de incentivar o lazer como forma de promoção social, considera o lazer como direito subjetivo fundamental da pessoa humana, que visa a refazer as forças do trabalhador depois da labuta diária e semanal, sendo a saúde física e mental, o desenvolvimento social e a melhoria da qualidade de vida dos bens jurídicos resguardados pela Carta Constitucional. Desta forma, pondera o professor que eventual lesão ao direito constitucional ao lazer configuraria ato ilícito, em razão da violação do dever jurídico originário de respeitar a ociosidade repousante, o convívio social e o divertimento das pessoas. Entretanto, o dano decorrente de tal lesão recairia sobre a saúde, o desenvolvimento social e a qualidade de vida, sobretudo do trabalhador, e não sobre o tempo que é suporte implícito da atividade lazer. Por fim, em relação ao tempo como suporte implícito da atividade de estudar, igualmente não se vislumbra, conforme lição de Dessaune, previsão constitucional relativamente ao tempo como sendo bem jurídico. ${ }^{24}$

A Constituição Federal, nos arts. $6^{\circ}, 205$ e 206, eleva a educação ao patamar dos direitos fundamentais do homem, tendo o Estado e a família o dever de prestá-la. Ao tratar da educação como direito constitucional da pessoa, a Carta Magna estabelece o

23 HOEPPNER, Marcos Garcia apud DESSAUNE, Marcos. Desvio produtivo do consumidor: prejuízo do tempo desperdiçado, cit., p. 123.

24 DESSAUNE, Marcos. Desvio produtivo do consumidor: prejuízo do tempo desperdiçado, cit., p. 124-128. 
conhecimento como objeto do direito à educação, ou seja, consagra o conhecimento como bem jurídico. A atividade de estudar, que é um modo de aquisição do conhecimento, não é nem direito nem bem jurídico em tal contexto, por conseguinte, o tempo, que é mero suporte implícito 'do estudo', igualmente carece da condição de bem jurídico. ${ }^{25}$

Sendo assim, restaria configurado, em tese, o ato ilícito em caso de violação do ato de estudar, no entanto, o dano resultante incidiria no conhecimento, que é o bem jurídico protegido constitucionalmente, e não sobre o tempo, haja vista que este é mero suporte implícito da atividade de estudar.

Por todo exposto, não obstante tratar-se inequivocamente do bem mais valioso de que dispõe o ser humano em sua vida, conforme restou demostrado no presente trabalho, Marcos Dessaune destaca a inexistência no ordenamento jurídico pátrio de norma expressa declarando o tempo como sendo bem jurídico, razão pela qual, ainda segundo o referido autor, inviabilizaria a ocorrência, tendo em vista o atual contexto, do que ele chamou 'desvio produtivo do consumidor indenizável' ${ }^{26}$

Em que pese respeitável o posicionamento de Marcos Dessaune relativamente ao não reconhecimento do tempo como bem jurídico, com ele não podemos concordar, ao menos parcialmente. Impõe-nos, no entanto, reconhecer a inequívoca constatação do insigne advogado em relação à inexistência de previsão expressa dispondo acerca do tempo com bem jurídico. Porém, a inexistência de previsão legal em tal sentido não inviabiliza o reconhecimento do tempo como bem jurídico.

Isto porque, de acordo com Anderson Schreiber, o ordenamento jurídico brasileiro, relativamente à seleção de interesses merecedores de tutela, é considerado atípico ou aberto, ou seja, não há no ordenamento pátrio previsão legal indicando taxativamente os interesses cuja violação origina um dano ressarcível, mas, tão somente, uma cláusula geral de ressarcimento pelos danos patrimoniais ou morais. ${ }^{27}$

Dito de outro modo, nos sistemas considerados abertos ou atípicos, como é o caso do brasileiro, o legislador cuida unicamente de estabelecer as cláusulas gerais de ressarcimento, cabendo ao Poder Judiciário, a partir de certa discricionariedade que lhe é atribuída, a seleção dos interesses merecedores de tutela no caso concreto.

Desta forma, a ausência de previsão legal expressa dispondo acerca da proteção de determinado interesse não inviabiliza seu reconhecimento, no caso concreto, como merecedor de tutela, apto a ensejar o dever de reparação diante de eventual lesão sofrida.

25 SILVA, José Afonso da. Curso de direito constitucional positivo. 13. ed. São Paulo: Malheiros, 1997. p. 102.

26 DESSAUNE, Marcos. Desvio produtivo do consumidor: prejuízo do tempo desperdiçado, cit., p. 129.

27 SCHREIBER, Anderson. Novos paradigmas da responsabilidade civil: da erosão dos filtros da reparação à diluição dos danos. 5. ed. São Paulo: Atlas, 2013. p. 103. 
Ao revés, restringir os interesses merecedores de tutela àqueles previstos previamente em lei se afigura, ante as múltiplas situações novas e expectativas que caracteriza as sociedades atuais, totalmente incompatíveis com a realidade jurídica contemporânea. ${ }^{28}$

Leciona Gustavo Tepedino, neste sentido, que as previsões legislativas, constitucionais ou ordinárias, não são capazes "de tutelar as irradiações da personalidade em todas as suas possíveis manifestações". E conclui asseverando que "com a evolução cada vez mais dinâmica dos fatos sociais, torna-se assaz difícil estabelecer disciplina legislativa para todas as possíveis situações jurídicas de que seja a pessoa humana titular". ${ }^{29}$

Com efeito, Schreiber aponta a "insuficiência da técnica regulamentar diante de realidade em constante mutação", rejeitando as correntes que pretendem selecionar os interesses merecedores de tutela baseando-se em uma prévia disposição legislativa, "seja sob a forma de direito subjetivo absoluto, seja por meio de qualquer outra categoria inflexível”.

Dessa forma, diferentemente de Dessaune, para o qual a inexistência de previsão expressa consagrando o tempo com bem jurídico inviabiliza a ocorrência das situações de 'desvio produtivo do consumidor' indenizáveis, Schreiber ensina que, na aferição do dano ressarcível no caso concreto, "cumpre verificar se o interesse dito lesado corresponde a um interesse merecedor de tutela em abstrato, ou seja, se vem protegido por alguma norma do ordenamento jurídico", não se exigindo, para tanto, "que a tutela venha expressamente declarada pela norma". ${ }^{30}$

Em outras palavras, para este último autor, há a possibilidade da ocorrência de dano ressarcível ainda que o interesse dito lesado não se apresente expressamente tutelado na norma. Basta, para o reconhecimento da existência do dano, a mera referência abstrata na norma relativamente ao merecimento de tutela do interesse lesado.

Sendo assim, não obstante a ausência de previsão expressa na lei relativamente ao tempo como bem jurídico, é possível, a partir da interpretação das normas constitucionais e de proteção do consumidor, identificar, no caso concreto, se o interesse ao tempo é merecedor de tutela, cuja violação ensejaria a consequente reparação.

Ademais, conforme Pablo Stolze Gagliano, o tempo pode ser considerado em dupla perspectiva: dinâmica e estática. Em sua perspectiva dinâmica, "o tempo é 'fato jurídico em sentido ordinário’, ou seja, um acontecimento natural, apto a deflagrar efeitos

\footnotetext{
28 SCHREIBER, Anderson. Novos paradigmas da responsabilidade civil: da erosão dos filtros da reparação à diluição dos danos, cit., p. 124.

29 TEPEDINO, Gustavo apud SCHREIBER, Anderson. Novos paradigmas da responsabilidade civil: da erosão dos filtros da reparação à diluição dos danos, cit., p. 125.

30 SCHREIBER, Anderson. Novos paradigmas da responsabilidade civil: da erosão dos filtros da reparação à diluição dos danos, cit., p. 164.
} 
na órbita do Direito". Enquanto isto, em sua perspectiva estática, “o tempo é um valor, um relevante bem, passível de proteção jurídica". ${ }^{31}$

Dessa forma, segundo o referido autor, diante de sua importância, o tempo pode ser considerado um bem merecedor de indiscutível tutela, isto é, bem jurídico.

Por todo exposto, podemos afirmar ser possível o reconhecimento do tempo, em que pese inexistir disposição expressa, como um interesse merecedor de tutela, apto a ensejar para aquele que eventualmente o lesar o dever de reparar o dano causado.

2. Do dever de indenizar o tempo desperdiçado

2.1. Desvio produtivo do consumidor

Conforme já apontado, Marcos Dessaune conclui que os consumidores dispõem de seis recursos nas relações de troca com o fornecedor, quais sejam: recursos naturais vulneráveis, recurso cognitivo abstrativo, recursos vitais vulneráveis, recursos produtivos limitados, recursos materiais limitados e recurso volitivo condicionado. ${ }^{32}$

Ainda, vimos que o tempo, ao lado das competências, trata-se de um recurso produtivo escasso. Sendo que, por "competência" é o conjunto de conhecimentos, habilidades e atitudes. São estes recursos, tempo e competência, que a pessoa humana necessita dispor para desempenhar qualquer atividade. Neste sentido, Dessaune identificou possuir os fornecedores de produtos e serviços a missão implícita de liberar os recursos produtivos do consumidor, isto é, de conceder aos consumidores condições de empregar seus recursos produtivos, quais sejam tempo e competências, nas atividades de suas preferências.

É demais sabido que o ser humano se utiliza das relações de troca para satisfazer suas necessidades e carências, ante a impossibilidade de produzir tudo aquilo que necessita. Tal situação é mais evidente na sociedade capitalista contemporânea, em que reina a especialização profissional, cujo resultado é a criação de uma relação de interdependência entre os membros da sociedade.

Desta forma, a fim de atingir determinados objetivos, considerados pela própria sociedade como dotados de significante valor, como a liberdade, a dignidade, o bem-estar, o desenvolvimento, a igualdade, entre outros, os indivíduos se valem, cada vez mais, das relações de troca, ou seja, do consumo.

Consequentemente, as pessoas consumidoras passaram a exigir que os produtos ou serviços disponibilizados no mercado possuam qualidade intrínseca, ou seja,

31 GAGLIANO, Pablo Stolze. Responsabilidade civil pela perda do tempo. Jus Navigandi, Teresina, ano 18, n. 3.540, 11 mar. 2013. Disponível em: <http://jus.com.br/artigos/23925>. Acesso em: 25 fev. 2015.

32 DESSAUNE, Marcos. Desvio produtivo do consumidor: prejuízo do tempo desperdiçado, cit., p. 93. 
que sejam adequados e seguros dentro daquilo em que é proposto, de modo a satisfazer suas necessidades e carências.

Sendo assim, nas relações de troca com os consumidores, de acordo com Dessaune, os fornecedores têm a missão de "contribuir para a existência digna, promover o bem-estar e possibilitar a realização humana do seu consumidor, bem como de eventuais empregados e sócios e da comunidade que o cerca, em função dos quais ele existe".

Portanto, dentro da perspectiva constitucional e infraconstitucional de proteção da dignidade da pessoa humana, da busca do bem-estar da pessoa e da defesa do consumidor, o fornecedor possuir o dever legal de disponibilizar no mercado de consumo produtos e serviços que detenham os padrões adequados de qualidade, de segurança, de durabilidade e de desempenho, a fim de serem efetivamente úteis e não causarem riscos ou prejuízos aos consumidores. Ainda, deve sempre o fornecedor agir de boa-fé e de se responsabilizar pelos danos que possa causar ou já tenha causado ao consumidor. Em outras palavras, o fornecedor tem o dever legal de atender às necessidades dos consumidores, respeitando sua dignidade, saúde e segurança, protegendo seus interesses econômicos e contribuindo para a melhoria de sua qualidade de vida.

No entanto, de maneira reiterada, os fornecedores, sejam eles profissionais autônomos ou liberais, empresas e o próprio Estado, ao invés de fornecer um produto ou serviço adequado e seguro, que satisfaça a necessidade do consumidor, desejos e expectativas, fornecem, na realidade, seja por negligência, desídia, despreparo ou máfé, "um produto final defeituoso, exercem uma prática abusiva no mercado ou cometem outros atos ilícitos, gerando algum tipo de risco ou de prejuízo para o consumidor, individual ou coletivamente". Isto é, contrariamente aos ditames de sua missão, qual seja a de contribuir para a existência digna do consumidor, promovendo seu bem-estar e liberando seus recursos produtivos, os fornecedores, de maneira corriqueira, submetem os consumidores a situação de mau atendimento, afrontando não só seus desejos e interesses, mas também a própria legislação protetiva do consumidor. ${ }^{33}$

Destarte, não obstante as previsões constantes no diploma protetivo do consumidor, qual seja o Código de Defesa do Consumidor, em que o fornecedor é obrigado a disponibilizar no mercado de consumo produtos e serviços adequados relativamente à qualidade, segurança, durabilidade e desempenho, bem como de agir sempre de boa-fé, vedando práticas abusivas, ainda são comuns situações como enfrentar uma fila demorada na agência bancária, ter que retornar à loja para reclamar de um produto defeituoso,

33 DESSAUNE, Marcos. Desvio produtivo do consumidor: prejuízo do tempo desperdiçado, cit., p. 130 e $42-$ 46. 
esperar por atendimento em consultório médico ou hospitalar ou odontológico, ou, ainda, ter negado pelo plano assistencial de saúde o exame exigido pelo médico, entre outros. ${ }^{34}$

Assim, ao disponibilizar no mercado de consumo um produto ou serviço defeituoso ou, até mesmo, ao realizar uma prática abusiva, o fornecedor submete o consumidor a situações de mau atendimento, na qual o consumidor é impelido a desperdiçar o seu tempo e desviar as suas competências a fim de ver solucionado um problema criado pelo fornecedor.

Dito de outra forma, em situações tais, o consumidor deixa de realizar certas atividades que deveria ou gostaria de executar, como o trabalho, o estudo, lazer, o descanso, entre outros, para sanar, a contragosto, um vício ou defeito constante de um produto ou serviço, o qual lhe causa prejuízo, desperdiçando seu tempo e suas competências.

Por todo o exposto, Dessaune conclui que o fornecedor, ao submeter o consumidor a situações de mau atendimento, entregando-lhe um produto ou serviço defeituoso, e, assim, descumprindo sua missão implícita que é, dentre outros, liberar os recursos produtivos do consumidor, comete ato ilícito, independentemente de culpa, impondo ao consumidor significativo e indesejável ônus produtivo. Tais situações, lesivas que são ao consumidor, Dessaune denominou de situações de 'desvio dos recursos produtivos do consumidor, ou, em suma, 'desvio produtivo do consumidor'. Faz importante ressalva o autor relativamente ao termo 'produtivo' empregado por ele nestas novas situações identificadas. Segundo tal, o adjetivo 'produtivo' fora utilizado em sua acepção de 'relativo à produção', indicando tão somente que em situações de mau atendimento o consumidor desvia recursos 'que produzem', quais sejam seu tempo e suas competências. Sendo assim, não utilizou o autor o termo 'produtivo' a fim de qualificar o desvio do consumidor como sendo algo 'producente' ou 'improducente'. ${ }^{35}$

Em síntese, portanto, de acordo com Dessaune, toda vez que o consumidor desvia seu tempo e suas competências, considerados recursos produtivos escassos, das atividades desejadas ou queridas para solucionar problemas constantes de produtos e serviços defeituosos, estar-se-ia diante de situações de desvio produtivo do consumidor.

No entanto, conforme relatado no tópico 3.3 do presente trabalho, o qual destinamos para a análise jurídica do tempo como provável bem jurídico, Dessaune afirma não existir previsão constitucional que consagre o tempo como objeto de direito, isto é, como bem jurídico.

Em contrapartida, relativamente às competências da pessoa consumidora, entendidas como sendo o "conjunto de conhecimentos ou saber, habilidades ou saber-fazer

\footnotetext{
34 DESSAUNE, Marcos. Desvio produtivo do consumidor: prejuízo do tempo desperdiçado, cit., p. 47.

35 DESSAUNE, Marcos. Desvio produtivo do consumidor: prejuízo do tempo desperdiçado, cit., p. 47-49 e 134.
} 
e atitudes ou saber-ser, necessário para o desempenho de uma atividade, seja qual for", entende o autor haver, diferentemente do tempo, previsão constitucional consagrando-as como bem jurídico.

Relativamente ao conhecimento, considerando este em sua acepção mais geral e vulgar, qual seja significando estudo, saber, desenvolvimento pessoal e erudição, Dessaune esclarece que a Constituição Federal, em seu art. 205, ao prever que a educação tem como função o desenvolvimento da dimensão individual da pessoa, está consagrando o 'conhecimento' como objeto do direito constitucional à educação, o qual, de acordo com José Afonso da Silva, foi elevado à categoria de direito fundamental do homem, sendo dever do Estado e da família sua prestação. ${ }^{36}$

Ainda, pode-se dizer ser a competência conhecimento objeto do direito constitucional da liberdade de aquisição e transmissão do conhecimento e da liberdade de informação das pessoas. Isto porque, a liberdade de ensinar, de aprender e de pesquisar são modos de aquisição do conhecimento e estão previstas no inciso II do art. 206 da Lei Maior. Tais liberdades de aquisição e transmissão do conhecimento estão intimamente relacionadas com a liberdade de informação, cunhada nos arts. $5^{\circ}$, XIV, e $220, \S 1^{\circ}$, da Carta Magna, sendo o conhecimento, por conseguinte, objeto do direito à liberdade de informação das pessoas.

Quanto à competência habilidade, entendida como "proficiência adquirida por meio do treinamento ou experiência profissional, de perícia profissional, de qualificação para o trabalho", ensina Dessaune estar, de igual modo à competência conhecimento, intimamente associada ao direito constitucional à educação, em razão de função constitucional da educação, insculpida no art. 205 da CF/1988, de desenvolvimento da dimensão profissional da pessoa, sendo, portanto, objeto de tal direito. ${ }^{37}$

A competência habilidade, ainda, encontra-se associada à liberdade de ação profissional, prevista no inciso XIII do art. $5^{\circ}$ da Lei Maior, isto é, à liberdade de escolha do trabalho e à liberdade de exercício do ofício, sendo considerada, portanto, bem jurídico protegido pela Constituição Federal.

Finalmente, a competência atitude, compreendia como sendo o “comportamento motivado, de ação ou omissão voluntária decorrente de uma crença ou convicção, de tomada de posição por razões de foro íntimo, de exercício consciente da cidadania", relaciona-se intensamente, de igual modo ao conhecimento e à habilidade, com o direito constitucional à educação, porém, neste caso específico, tendo em vista a função da educação de desenvolvimento da dimensão sociopolítica da pessoa.

SILVA, José Afonso da. Curso de direito constitucional positivo, cit., p. 103.

DESSAUNE, Marcos. Desvio produtivo do consumidor: prejuízo do tempo desperdiçado, cit., p. 115-132. 
Além de objeto do direito à educação, a competência atitude também está intimamente relacionada à liberdade de ação da pessoa, prevista no art. $5^{\circ}$, inciso II, da $\mathrm{CF} / 1988$, bem como à liberdade de pensamento, insculpida no inciso IV, VI, IX, do art. $5^{\circ}$, inciso II do art. 206 e caput do art. 220, todos da nossa Lei Maior. É portanto bem jurídico protegido pela Constituição Federal.

Portanto, diante da proteção dispensada na Constituição Federal relativamente às competências conhecimento, habilidade e atitude, sendo consideradas, conforme relatado, bens jurídicos constitucionais, Dessaune leciona que "eventual lesão direta de uma delas poderia acarretar um dano de natureza moral e/ou material, por ato ilícito", tendo em vista disposição constitucional no sentido da inviolabilidade de determinados bens e interesses da pessoa.

No entanto, ressalta o autor que "nas situações de mau atendimento, o consumidor geralmente não chega a ter suas custosas competências lesionadas", na realidade, em situações tais, o consumidor “"apenas' as desvia de suas atividades indispensáveis ou preferidas, sem que isso em princípio configure um dano previsto em nosso ordenamento jurídico".

Ou seja, segundo Dessaune, em situações em que o fornecedor entrega ao consumidor um produto final defeituoso ou exerce no mercado de consumo uma prática abusiva, compelindo o consumidor a sanar um defeito que não deu causa, não há dano, ao menos previsto legalmente, mas apenas um 'desvio' das competências de atividades desejadas ou indispensáveis do consumidor.

Dessa forma, tendo em vista que em situações de mau atendimento o consumidor apenas 'desvia' suas competências, identificadas estas como conhecimento, habilidade e atitude da pessoa consumidora, não configurando dano, ao menos legalmente, e, ainda, considerando inexistir previsão legal consagrando o tempo como bem jurídico dotado de proteção, Dessaune conclui não haver, em princípio, a possibilidade da ocorrência de "situações de desvio produtivo indenizáveis pelo fornecedor".

Neste sentido, assevera o autor que esta nova modalidade de dano, a qual ele denominou "desviou produtivo do consumidor", não possui ainda guarida no ordenamento jurídico brasileiro, o que inviabiliza a responsabilização dos fornecedores quando estes submetem o consumidor a situações de mau atendimento, isto é, quando entregam um produto ou serviço defeituoso, ou, ainda, quando exercem no mercado uma prática ilegal, obrigando o consumidor a desperdiçar o seu tempo e desviar suas competências a fim de sanar um prejuízo que não deu causa.

A fim de que surja, assim, para o fornecedor o dever jurídico de reparar o dano causado ao consumidor em situações de 'desvio produtivo', é indispensável prévia disposição constitucional acerca das circunstâncias e consequências deste 'novo dano' identificado. 
Visto isto, Dessaune, com o intuito de proteger os indivíduos deste dano, propõe a inserção de um novo dispositivo na Constituição Federal com a seguinte redação:

O tempo de que cada indivíduo dispõe na vida, caracterizado pela escassez, inacumulabilidade e irrecuperabilidade, é recurso produtivo primordial e inviolável da pessoa, assegurando-se a ela o direito à indenização do dano de desvio produtivo decorrente da lesão desse seu tempo pessoal. $^{38}$

Não temos dúvidas que a inserção de dispositivo na Constituição Federal prevendo expressamente a possibilidade de responsabilização do fornecedor nas situações de desvio produtivo garantiria maior eficácia à reparação do dano temporal causado ao consumidor. No entanto, acreditamos que a atual ausência de previsão expressa em tal sentido não inviabiliza o reconhecimento do prejuízo causado ao consumidor relativamente à perda do tempo suportada.

Ao contrário, entendemos que o ordenamento pátrio nos garante subsídios legais e principiológicos suficientes para impor ao fornecedor o dever de reparar o dano temporal causado ao consumidor, sem necessitar, por conseguinte, de previsão expressa específica.

2.2. Adoção da teoria da responsabilidade civil pela perda do tempo útil pelos tribunais

"Mero dissabor". "Aborrecimento normal e inevitável". É assim que a grande maioria dos Tribunais vêm tratando as inaceitáveis situações de mau atendimento que são submetidos os consumidores quase que diariamente. Situações estas que impõem aos consumidores uma perda inestimável do pouco tempo que dispõe na vida. Inestimável porque, conforme relatamos, trata-se do capital mais valioso do ser humano.

Inobstante tratar-se de um bem primordial para a pessoa e mais importante capital que dispõe em sua vida, os Tribunais, ao tratar como mero dissabor ou aborrecimento normal e inevitável situações como a interminável fila do banco, ou a longa espera para receber atendimento hospitalar ou ambulatorial, ou, ainda, a espera demasiada na linha telefônica na tentativa de cancelamento de serviço ou de cobrança indevida via Serviço de Atendimento ao Cliente (SAC), vêm admitindo, de forma negligente, que os fornecedores, utilizando-se de sua superioridade econômica, técnica e jurídica, obriguem os consumidores a desperdiçar intoleravelmente seu precioso tempo livre.

No entanto, felizmente, parte da jurisprudência vem contribuindo paulatinamente para alterar este cenário de desídia relativamente ao tempo, não mais

38 DESSAUNE, Marcos. Desvio produtivo do consumidor: prejuízo do tempo desperdiçado, cit., p. 136. 
considerado como mero aborrecimento a perda do tempo vivenciada pelo consumidor nas relações de consumo. Ao adotarem a Teoria da Responsabilidade Civil pela Perda do Tempo Útil, os Tribunais, reconhecendo a merecida importância do tempo na vida da pessoa consumidora, passaram a admitir a responsabilização dos fornecedores pela perda do tempo útil do consumidor, condenando-os ao pagamento de indenizações por dano moral.

Na vanguarda desta alteração de paradigma encontra-se, notadamente, o Tribunal de Justiça do Estado do Rio de Janeiro, o qual, já há algum tempo, vem adotando a responsabilidade civil do fornecedor pela perda do tempo nos casos de mau atendimento e má prestação de serviços. Seguindo tal tendência, outros Tribunais, como o do Rio Grande do Sul, Minas Gerais e Pernambuco, vêm, igualmente, ainda que de maneira mais acanhada, responsabilizando os fornecedores de produtos e serviços pela perda do tempo do consumidor.

Cumpre ressaltar que a adoção, pelos tribunais, da teoria da perda do tempo útil representou a inauguração de uma nova modalidade de dano moral no ordenamento jurídico pátrio. Ao responsabilizar os fornecedores pela perda do tempo do consumidor, ampliou-se o conceito do dano moral, passando-se este a englobar situações de mau atendimento, nas quais o consumidor se vê obrigado a perder seu tempo livre em razão de um ato ilícito ou abusivo perpetrado pelo fornecedor. Reconheceu-se, ainda que tardiamente, a importância do tempo na vida das pessoas, passando-se a considerá-lo como verdadeiro bem jurídico, merecedor da devida tutela jurídica, vedando-se qualquer prática capaz de lesar tal bem.

É o que pode ser notado, por exemplo, em decisão proferida pela Nona Câmara Cível do Tribunal de Justiça do Rio de Janeiro, em ação promovida em face da empresa TAM Linhas Aéreas S.A.. ${ }^{39}$

O Desembargador Rogério de Oliveira Souza, adotando a teoria da responsabilidade civil pela perda do tempo útil, condenou a empresa ao pagamento de danos morais em favor do consumidor, em razão dos transtornos ocasionados pelo atraso injustificável no voo e que provocou a perda do voo de conexão ao destino contratado. Destacou o Relator que no conceito contemporâneo de obrigação, esta não mais se presta à simples aquisição de riqueza, mas à efetivação de direitos constitucionais. Ainda, afastou a alegação de "mero aborrecimento", evidenciando o prejuízo sofrido pelos consumidores ante a perda do tempo ocasionada pelo atraso no voo contratado. Por fim,

39 RIO DE JANEIRO. Tribunal de Justiça. Apelação Cível: 0349094-50.2011.8.19.0001. Apelante: TAM Linhas Aéreas S.A.. Apelado: Luciano Martins de Araujo e Vanessa Monteiro de Albuquerque. Relator: Des. Rogério de Oliveira Souza. Rio de Janeiro, RJ, 11/01/2013. 
ressaltou o caráter pedagógico da indenização, a qual deverá servir de reprimenda pela ofensa perpetrada injustamente em face dos consumidores.

Ainda no Estado do Rio de Janeiro, novamente a Nona Câmara Cível, em ação promovida em face de GARANTECH GARANTIAS E SERVIÇOS SC LTDA, GLOBEX UTILIDADES S.A. e RC DE CABO FRIO COMPONENTES ELETRÔNICOS LTDA., condenou os Réus, solidariamente, ao pagamento de indenização a título de danos morais, bem como à devolução do valor pago pelo produto, em razão da falha na prestação do serviço, bem como em razão da excessiva demora na solução do problema do consumidor. ${ }^{40}$

Esclareceu o magistrado que, ao ser detectado o vício no produto adquirido pelo consumidor, deveriam os fornecedores, responsáveis solidários que legalmente eram, franquearem ao consumidor as opções previstas no art. 18, § $1^{\circ}$, do Código de Defesa do Consumidor. No entanto, fizeram, na realidade, exatamente o contrário. Tratando o consumidor com descaso, obrigaram-no a desperdiçar seu tempo em diversas, sucessivas e infrutíferas tentativas de solucionar o problema constante no produto. Diante de tal cenário, não teve como o Relator decidir de maneira diversa senão pela condenação dos Réus, de forma solidária, ao pagamento de indenização a título de danos morais e materiais ao consumidor.

$\mathrm{Na}$ esteira do entendimento adotado pelo Tribunal de Justiça do Rio de Janeiro, outros Tribunais de Justiça, como o do Rio Grande do Sul e Minas Gerais, também vêm aplicando, ainda que pontualmente, a teoria da perda do tempo útil e responsabilizando as empresas pelo prejuízo temporal causado ao consumidor.

Em recente decisão proferida pelo Tribunal de Justiça de Minas Gerais, a Décima Quarta Câmara Cível, em julgamento de recurso de apelação, manteve a decisão de primeira instância, a qual condenou a empresa Ré PARMA DESIGN COMÉRCIO DE MÓVEIS LTDA. ao pagamento de danos morais ao consumidor, fundamentando que, em situações de mau atendimento em que o consumidor é obrigado a desperdiçar seu tempo na tentativa de exigir do fornecedor o cumprimento de sua obrigação, há lesão a direito da personalidade da pessoa consumidora, ensejando a devida reparação. ${ }^{41}$

$\mathrm{Na}$ decisão, ressaltou o Desembargador Estevão Lucchesi a mudança de tratamento por parte da jurisprudência relativamente ao tempo desperdiçado do consumidor, o qual deixou de ser considerado como mero aborrecimento, passando a

40 RIO DE JANEIRO. Tribunal de Justiça, Apelação Cível: 0004093-56.2009.8.19.0011. Apelante: Adriana Pinna Barreto. Apelado: Garantech Garantias e Serviços SC Ltda. e Outros. Relator: Des. Rogerio de Oliveira Souza. Rio de Janeiro, RJ, 16/04/2013.

41 MINAS GERAIS, Tribunal de Justiça, Apelação Cível: 1.0145.12.016588-4/001. Apelante: Parma Design Comércio de Móveis Ltda. e Carlos Roberto Venanzoni. Apelado: Os mesmos. Relator: Des. Estevão Lucchesi. Juiz de Fora, MG, 23/05/2014. 
ser considerado como dano indenizável, haja vista tratar-se de ofensa aos direitos da personalidade do consumidor, bem como em razão das constantes situações de mau atendimento que são submetidos os consumidores quase que diariamente.

No Estado do Rio Grande do Sul, a Primeira Câmara Especial Cível do Tribunal de Justiça do Estado, em acórdão proferido, condenou o Departamento Municipal de Água e Esgoto (DMAE) ao pagamento de indenização ao consumidor, a título de danos morais, ante as inúmeras tentativas frustradas do consumidor de cancelamento junto ao fornecedor de cobrança indevida, o que acarretou ao consumidor transtornos e contratempos, além da intolerável perda do tempo. ${ }^{42}$

Enalteceu o Relator Desembargador a importância do decurso do tempo em nossas vidas, na medida em que tal é suporte para a confraternização familiar, para o lazer, para o trabalho, entre outros, além de tratar-se de um bem escasso, haja vista a pouca disponibilidade de tempo livre na vida das pessoas consumidoras. Sendo assim, são inaceitáveis situações em que os consumidores são obrigados a desviar seu tempo das atividades que desejava realizar, como o descanso, o lazer, para resolver problemas causados pelos fornecedores no mercado de consumo.

Fundamentou a decisão, ainda, alegando que competia à autarquia municipal o imediato atendimento à solicitação do consumidor, efetuando o cancelamento da cobrança logo que constatado o equívoco e denunciado pelo cliente. Porém, desprezando a reclamação do consumidor, não o fez, deixando de solucionar o problema da cobrança indevida. Agindo o fornecedor, portanto, de maneira desidiosa, obrigou o consumidor a dispender parte de seu tempo útil para solucionar o problema que o próprio fornecedor dera causa. Assim, deve o fornecedor reparar o dano causado ao consumidor, indenizando-o.

Da análise dos diversos julgados em que se admitiu a teoria da perda do tempo útil do consumidor, impõe-nos destacar o reconhecimento, em inúmeros casos, do dano moral in re ipsa. Isto é, segundo os tribunais, nos casos em que o consumidor é compelido a desperdiçar seu tempo na tentativa de solucionar problemas causados pelo fornecedor ou quando é obrigado a recorrer ao judiciário a fim de ver seu direito garantido presume-se a ocorrência do dano, restando-se dispensada a comprovação do abalo psicológico sofrido pela vítima.

Outra importante observação faz-se necessária relativamente ao caráter do dano moral adotado em alguns julgamentos. Muitos julgadores, ante as corriqueiras situações de mau atendimento a que são submetidos os consumidores e a fim de evitar a reiteração de tais práticas por parte dos fornecedores, foram além do caráter reparatório

42 RIO GRANDE DO SUL, Tribunal de Justiça, Apelação Cível e Reexame Necessário n. 70003750700, Relator: Des. Adão Sérgio do Nascimento Cassiano, Data de Julgamento: 24/06/2003, Primeira Câmara Especial Cível. 
do dano moral e, embasados na Teoria do Desestímulo, aplicaram-no, a nosso ver de maneira correta, em sua função pedagógica/punitiva. É imprescindível que a indenização imposta não ser torne inócua frente a capacidade econômica dos fornecedores, de tal forma a servir como desestímulo a reiteração de práticas lesivas ou abusivas no mercado de consumo. Ou seja, é preciso desconstruir a noção de que "o crime compensa", isto é, contextualizando, de que é mais vantajoso a reiteração de práticas lesivas ou abusivas que a sua não-reiteração.

Por fim, a adoção da Teoria da Responsabilidade Civil Pela Perda do Tempo Útil pelos tribunais, ainda que em alguns se apresente apenas pontualmente, representa um importante avanço no tratamento do tema na jurisprudência nacional. É um gigantesco passo dado na direção da concretização daquilo que a própria Constituição Federal determina: a proteção do consumidor nas relações de consumo. Ainda, é um marco em relação ao tratamento jurídico dispensando ao tempo, até então negligenciado por nosso ordenamento jurídico, bem como por nossos tribunais, os quais, na maioria das vezes, viam como 'aceitáveis' as inaceitáveis e constantes situações de perda do tempo vivenciadas pelos consumidores, reduzindo-as a meros dissabores, aborrecimentos normais e inevitáveis.

\subsection{Dano temporal: uma nova modalidade de dano}

Conforme relatado no item 2.2. do presente trabalho, o qual destinamos ao estudo do conceito de responsabilidade civil, verificamos que se entende por responsabilidade civil como sendo um "dever jurídico sucessivo que surge para recompor o dano decorrente da violação de um dever jurídico originário". ${ }^{43}$

Vimos, também, que a responsabilidade civil, de modo geral, é composta por três elementos ou pressupostos, quais sejam a conduta culposa, o dano e o nexo de causalidade. Referimos-nos à responsabilidade civil de modo genérico porque, como é sabido, a responsabilidade civil objetiva prescinde de comprovação de culpa, isto é, não se faz necessária a verificação da culpabilidade do agente. Desta forma, relativamente à responsabilidade civil objetiva, temos como elementos ou pressupostos a conduta antijurídica, pouco importando se culposa ou dolosa, o nexo de causalidade e o dano.

O dano é a pedra fundamental da responsabilidade civil, o elemento indispensável para sua configuração, de tal modo que verificada sua inocorrência, não há falar no dever de indenizar. Ainda, conceituamos o dano com sendo uma lesão a um bem ou interesse juridicamente tutelado.

43 CAVALIERI FILHO, Sergio. Programa de responsabilidade civil. 11. ed. São Paulo: Atlas, 2014. p. 23-24. 
O nexo de causalidade, como pressuposto da responsabilidade civil, é entendido como sendo a relação de causa e efeito entre a conduta ilícita do agente e o dano causado. É o liame existente entre a conduta perpetrada pelo agente e o dano suportado pela vítima. Igualmente ao dano, não verificada a sua ocorrência, isto é, não constatado que o dano é resultado da conduta, inexiste o dever de indenizar.

Por sua vez, a culpa pode ser estudada a partir de dois sentidos: culpa em sentido amplo ou genérica (latu sensu) e culpa em sentido estrito ou stricto sensu. $\mathrm{Na}$ culpa em sentido amplo ou genérica, temos a presença do dolo e da culpa stricto sensu. Por culpa em sentido estrito ou stricto sensu, entende-se como sendo o agir contrário ao dever de cuidado imposto pelo Direito.

Não é demais ressaltar que a culpa não se apresenta como elemento obrigatório da responsabilidade civil objetiva, ou seja, não se faz necessária a prova da culpa do agente para sua responsabilização.

Ressalta-se, ainda, que a responsabilidade objetiva é a regra do Código de Defesa do Consumidor, consoante se depreende dos arts. 12, 14, 18 e 20. A objetivação da responsabilidade se justifica ante os objetivos almejados pelo código consumerista, qual seja a proteção do consumidor.

A fim de efetivar tal desígnio, o código assegura ao consumidor, em seu art. $6^{\circ}, \mathrm{VI}$, o direito à efetiva prevenção e reparação de danos, consagrando o princípio da reparação integral dos danos. Tal princípio impõe ao fornecedor o dever de reparar integralmente eventuais danos causados aos consumidores, inclusive os que acarretam na perda do tempo do consumidor, usualmente denominado dano temporal.

Além do dever de reparar integralmente todos os danos causados aos consumidores, corolário do princípio da reparação integral dos danos, os fornecedores possuem, também, o dever de disponibilizar no mercado de consumo produtos ou serviços com adequados padrões de qualidade, de segurança, de durabilidade e de desempenho, que sejam efetivamente úteis e que atendam as expectativas do consumidor, bem como não causem eventuais danos ou prejuízos.

Possuem, ainda, os fornecedores o dever de sempre agir com boa-fé, com probidade, lealdade, honestidade, ética, além de respeitar seu parceiro contratual (o consumidor), seus interesses legítimos e suas expectativas. Não se pode deixar de mencionar o dever de informar, de prestar informações claras, corretas e precisas sobre produtos e serviços disponibilizados no mercado de consumo. ${ }^{44}$

Em suma, os fornecedores possuem a missão, conforme apontado por Marcos Dessaune, de contribuir para a existência digna do consumidor, promover seu

44 CAVAliERI FILHO, Sergio. Programa de direito do consumidor. 3. ed. São Paulo: Atlas, 2011. p. 43. 
bem-estar e possibilitar sua realização humana. Ainda, de acordo com o referido autor, os fornecedores também têm a missão implícita de liberar os recursos produtivos do consumidor, quais sejam tempo e suas competências, a fim de que os empregue nas atividades de sua preferência..$^{45}$

No entanto, de forma reiterada, os fornecedores ignoram os desígnios a eles impostos pela legislação, exercem no mercado de consumo práticas abusivas, disponibilizam produtos ou serviços defeituosos e inadequados aos fins a que se destinam, tratam os consumidores com descaso e má-fé e, ainda, obrigam-nos a desperdiçar parte de seu precioso tempo na tentativa de solucionar os problemas que eles mesmos, fornecedores, deram causa. De um modo geral, frustram as expectativas dos consumidores relativamente ao produto ou serviço adquirido, ao atendimento que deveria lhe ser dispensado.

Dessa forma, ao obrigar o consumidor a esperar demasiadamente por atendimento na fila do banco ou nas clínicas ambulatoriais; ou, ao fornecer um produto final sem os devidos padrões de qualidade e segurança; ou, ao cobrar indevidamente por um produto ou serviço que sequer foi prestado ou vendido e, ainda, dificultar ao consumidor o cancelamento da cobrança, bem como negar a devolução, em dobro, da quantia paga indevidamente; ou, ao deixar de solucionar o problema constante no produto ou serviço dentro do prazo legal; ou, ao negar-se, quando for do interesse do consumidor, a trocar o produto defeituoso ou a devolver o valor pago; ou, ainda, ao manter o consumidor por horas pendurado na linha telefônica, a fim de 'convencer-lhe' pelo cansaço a continuar com o serviço contratado; em suma, ao proceder, portanto, de tais formas, os fornecedores violam diretamente seu dever jurídico originário de prestar o serviço na forma em que fora contratado e nos moldes em que o consumidor esperava que fosse cumprido, rompendo com os ditames da boa-fé objetiva, bem como frustrando as reais expectativas no consumidor, causando-lhes inequívocos prejuízos.

Por conseguinte, a violação ao dever jurídico originário de agir sempre com boa-fé, de disponibilizar produtos e serviços seguros, de reparar integralmente os danos causados aos consumidores dentro do prazo estipulado, de prestar informações claras, precisas e corretas, entre outros, faz surgir para o fornecedor a responsabilidade civil de indenizar o consumidor pelos danos eventualmente causados, ou seja, consoante se verificou no presente trabalho acerca da responsabilidade civil, surge para o fornecedor o dever jurídico sucessivo de reparar o dano causado em razão da violação de um dever jurídico originário.

No entanto, conforme já reiterado no presente trabalho, a responsabilidade de reparar somente nasce para o agente quando presente o dano. O dano é, dessa forma,

45 DESSAUNE, Marcos. Desvio produtivo do consumidor: prejuízo do tempo desperdiçado, cit., p. 42. 
o objeto e a ratio da reparação, entendendo a jurisprudência recente ser ele apto a atrair, ainda que isoladamente, a reparação dos infortúnios mais diversos. É preciso, portanto, a fim de surgir o dever jurídico de reparar, a ocorrência do dano, sendo este entendido como sendo a lesão a um bem ou interesse juridicamente protegido. ${ }^{46}$

Constatamos, no item 3.1., ser o tempo o capital maior mais valioso de que dispõe o ser humano em sua vida. ${ }^{47} \mathrm{O}$ tempo é, também, o meio pelo qual floresce o 'ócio criativo', isto é, é no tempo livre que o homem cria, estuda, se diverte, mantém relações interpessoais e familiares, descansa, joga, inventa, ama, ou seja, desfruta os prazeres mais singelos da vida. ${ }^{48}$ Ainda, trata-se o tempo de um bem irrecuperável, intangível, inacumulável e escasso. O tempo é, em suma, a própria existência humana, é por meio dele que o ser humano se realiza.

Em seguida, vimos ser possível o tempo ser considerado bem merecedor de tutela. Em razão de o sistema jurídico brasileiro ser considerado atípico ou aberto relativamente à seleção dos bens merecedores de tutela, isto é, o ordenamento pátrio não prevê um rol taxativo de interesses tutelados, limitando-se a prever uma cláusula geral de ressarcimento pelos danos patrimoniais ou morais (art. 927 do Código Civil), cabe ao magistrado, na análise do caso concreto, ponderar se o bem ou interesse alegadamente lesado é merecedor de tutela. Com efeito, não se exige a previsão expressa consagrando determinado bem ou interesse como merecedor da tutela. Faz-se necessário, apenas, que o interesse dito lesado corresponda a um interesse merecedor de tutela em abstrato. Assim, o magistrado, diante da análise do caso concreto, decidirá se o tempo, então interesse lesado, é merecedor de tutela, cuja violação enseja um dano ressarcível. ${ }^{49}$

Visto isto e considerando ser o tempo o meio para a realização de diversos direitos constitucionalmente assegurados, como o direito à educação, ao lazer, ao trabalho, à vida, bem como tendo em vista ser o tempo o meio no qual floresce o ócio criativo, o bem mais valioso do ser humano, entre outros caracteres que o tornam especial, é inquestionável tratar-se o tempo de um bem ou interesse merecedor de tutela.

Sendo assim, em situações em que o consumidor é obrigado a desviar seu tempo e suas competências das atividades que deveria ou desejaria realizar, como o trabalho, o descanso, o convívio familiar, para solucionar um problema que não deu causa, está-se

46 SCHREIBER, Anderson. Novos paradigmas da responsabilidade civil: da erosão dos filtros da reparação à diluição dos danos, cit., p. 83.

47 JÖNSSON apud DESSAUNE, Marcos. Desvio produtivo do consumidor: prejuízo do tempo desperdiçado, cit., p. 103.

48 DE MASI apud DESSAUNE, Marcos. Desvio produtivo do consumidor: prejuízo do tempo desperdiçado, cit., p. 100.

49 SCHREIBER, Anderson. Novos paradigmas da responsabilidade civil: da erosão dos filtros da reparação à diluição dos danos, cit., p. 103 e 164. 
diante de um dano inequívoco e intolerável, uma vez que o tempo desperdiçado em tal tarefa é irrecuperável. Em casos tais, o consumidor tem uma parcela do seu tempo retirada de sua disponibilidade de forma involuntária. Repita-se, parcela de tempo destinado ao convívio familiar, ao lazer, ao trabalho, ao descanso, aos diversos prazeres da vida, isto é, tempo destinado a concretização dos diversos direitos fundamentais consagrados na própria Constituição Federal, que injustamente lhe é usurpada.

Portanto, quando o fornecedor disponibiliza no mercado de consumo produtos ou serviços defeituosos e, em vez de prontamente solucionar os problemas verificados, trata o consumidor com desídia e descaso, deixando de sanar a falha dentro do prazo legal, compelindo-o, assim, a desviar seu tempo das atividades desejadas, como o lazer, o trabalho, o convívio familiar, para solucionar o problema verificado, acaba violando seu dever jurídico originário e causando inequívoco dano ao consumidor, representado pela perda do tempo. Consequentemente, violado um dever jurídico originário e verificada a ocorrência do dano, exsurge para o fornecedor o dever de indenizar a lesão causada, isto é, o dever de indenizar o tempo desperdiçado.

\section{Conclusão}

Diariamente, inúmeros consumidores, espalhados por todos os cantos do país, são obrigados a desperdiçarem, injustamente, parcela de seu precioso tempo na tentativa de solucionar um problema constante de um produto ou serviço adquiridos no mercado de consumo. Um problema que, frise-se, não foi por ele, consumidor, causado.

Seja por negligência, descaso ou, até mesmo, má-fé, os fornecedores de produtos e serviços, em vez de cumprir com sua missão, contribuindo para a existência digna do consumidor, promovendo seu bem-estar e contribuindo para sua realização pessoal, exercem no mercado de consumo práticas ilícitas ou abusivas, disponibilizam produtos ou serviços inadequados, violam o dever jurídico que lhe são impostos, acarretando, assim, danos aos consumidores.

Dessa forma, em situações em que os fornecedores disponibilizam no mercado de consumo um produto final defeituoso ou exercem no mercado uma prática abusiva, obrigam o consumidor a desperdiçar seu tempo e desviar suas competências das atividades necessárias ou preferidas para sanar o problema criado pelo próprio fornecedor. Situações tais que geram evidente dano malquisto ao consumidor.

No presente artigo, buscamos realizar uma abordagem acerca desta nova modalidade de dano, denominado de 'desvio produtivo do consumidor' ou, conforme adotado pela jurisprudência, perda do tempo útil do consumidor, ou, simplesmente, dano temporal. 
Vimos a importância do tempo em nossas vidas, podendo-se afirmar ser talvez o maior e mais valioso capital do homem. O pouco tempo livre de que dispomos diariamente pode ser destinado ao lazer, ao descanso, à arte, ao estudo, à convivência familiar; enfim, aproveitando-o como suporte para o florescimento do 'ócio criativo'. As características do tempo que o transformam em um bem único, quais sejam a intangibilidade, irrecuperabilidade, inacumulabilidade e escassez.

Diante de tal relevância para a vida das pessoas, bem como por tratar-se do meio no qual se concretiza os direitos fundamentais consagrados na Constituição Federal, como o direito à educação, direito à vida, ao lazer, entre outros, destacamos que, não obstante a ausência de previsão expressa tutelando o tempo como bem jurídico, é possível, no caso concreto, determinar ser o tempo um interesse merecedor de proteção, cuja violação enseja o dever de reparar.

Em outras palavras, consoante restou tratado, a inexistência de tutela expressa em relação ao tempo não inviabiliza que tal seja reconhecido como interesse protegido, ou seja, como bem jurídico, de tal sorte que eventual lesão ao bem tempo ensejaria ao causador do dano o dever de repará-lo. Daí poder se afirmar ser o dano temporal uma nova modalidade de dano ressarcível. Isto porque, o ordenamento jurídico brasileiro no que se refere à seleção dos bens merecedores de tutela é considerado aberto ou atípico, ou seja, não há no ordenamento pátrio elenco taxativo dos bens tuteláveis. $\mathrm{O}$ ordenamento brasileiro, na realidade, restringe-se a prever uma cláusula geral de ressarcimento de dano, cabendo ao Poder Judiciário a seleção, por meio da análise do caso concreto, dos bens ou interesses merecedores de tutela.

Não obstante a possibilidade de haver norma expressa que consagre $o$ tempo bem jurídico objeto de tutela para que as ofensas pudessem ser ressarcidas de forma indiscutível, isso poderia ser feito inclusive por meio de disposição constitucional. Isto é, o tempo seria um bem expressamente tutelado assim como a vida, a liberdade, a intimidade, a honra, a imagem; não restando margem para interpretações acerca da ressarcibilidade do dano temporal.

A inclusão de dispositivo consagrando o tempo como merecedor de tutela, reconhecendo sua imensurável importância, além de trazer maior segurança jurídica, concretizaria ainda mais a proteção constitucional do consumidor nas relações de consumo, garantindo-lhes efetivamente a plena e integral reparação dos danos suportados no mercado de consumo.

Ainda que a grande maioria da jurisprudência considere como mero aborrecimento as intoleráveis situações de mau atendimento a que são submetidos corriqueiramente os consumidores, as quais acarretem em inestimável perda do tempo, alguns poucos Tribunais, com maior destaque para o Tribunal do Estado do Rio de Janeiro, vêm, pouco a pouco, reconhecendo a importância do tempo na vida da pessoa 
consumidora, condenando os fornecedores ao pagamento de indenização por danos morais em favor dos consumidores nos caos de desperdício de tempo.

Contudo, o reconhecimento do dano temporal como uma nova modalidade de dano ressarcível é medida que se impõe em razão, dentre outras: da elevada importância do tempo, considerado o maior e mais valioso bem de que dispõe o ser humano; da possibilidade de reconhecimento do tempo como interesse merecedor de tutela; do dever jurídico dos fornecedores de cumprirem sua missão, fornecendo aos consumidores produtos finais adequados, seguros, duráveis, úteis, bem como atuando sempre com boafé e reparando integralmente os danos eventualmente causados aos consumidores; da necessidade da plena concretização da justiça; e, por fim, da realização constitucional da proteção do consumidor.

Londrina, 9 de março de 2015.

\section{Referências}

ABBAGNANO, Nicola. Dicionário de filosofia. Trad. Ivone Castilho Benedetti e Alfredo Bosi. 4. ed. São Paulo: Martins Fontes, 2003.

ALLEGRO, Romana Affonso de Almeida. Bens jurídicos: o interesse estatal de tutelar bens jurídicos através de sua normatização. Disponível em: <http://www.diretonet.com.br/artigos/exibir/2089/ Bens-juridicos>. Acesso em: 03 mar. 2015.

CAVALIERI FILHO, Sergio. Programa de direito do consumidor. 3. ed. São Paulo: Atlas, 2011.

. Programa de responsabilidade civil. 11. ed. São Paulo: Atlas, 2014.

COMTE-SPONVILLE, André. Dicionário filosófico. Trad. Eduardo Brandão. São Paulo: Martins Fontes, 2003.

DESSAUNE, Marcos. Desvio produtivo do consumidor: o prejuízo do tempo desperdiçado. São Paulo: Editora Revista dos Tribunais, 2011.

DINIZ, Maria Helena. Curso de direito civil brasileiro. 2. ed. São Paulo: Saraiva, 2009. v. 7.

GAGLIANO, Pablo Stolze. Responsabilidade civil pela perda do tempo. Carta Forense, abril de 2013.

. Responsabilidade civil pela perda do tempo. Jus Navigandi, Teresina, a. 18, n. 3.540, 11 mar. 2013. Disponível em: <http://jus.com.br/artigos/23925>. Acesso em: 25 fev. 2015.

GOMES, Luiz Flávio. Norma e bem jurídico no direito penal: normas penais primárias e secundárias; normas valorativas e imperativas; introdução ao princípio da ofensividade; lineamento da teoria constitucional do fato punível; teoria do bem jurídico-penal; o bem jurídico protegido nas falsidades documentais. São Paulo: Revista dos Tribunais, 2002. 
GONÇALVES, Carlos Roberto. Direito civil brasileiro. 4. ed. São Paulo: Saraiva, 2010. v. 4. . Responsabilidade civil. 11. ed. São Paulo: Saraiva, 2009.

GUGLINSKI, Vitor. Danos morais pela perda do tempo útil: uma nova modalidade. Jus Navigandi, Teresina, a. 17, n. 3.237, 12 maio 2012. Disponível em: <http://jus.com.br/artigos/21753>. Acesso em: 25 fev. 2015.

KUGUIMIYA, Luciana Lie. Responsabilidade civil pela usurpação indevida do tempo útil. Jus Navigandi, Teresina, a. 18, n. 3.805, 1 dez. 2013. Disponível em: <http://jus.com.br/artigos/25939>. Acesso em: 25 fev. 2015.

KURY, Mário da Gama. Dicionário de mitologia. 5. ed. Rio de Janeiro: Jorge Zahar Editor, 1999.

LÉLLIS, Leonardo. Tempo gasto em problema de consumo deve ser indenizado. Disponível em: $<$ http://www.conjur.com.br/2014-mar-26/tempo-gasto-problema-consumo-indenizado-apontamdecisoes>. Acesso em: 21 fev. 2015.

LISBOA, Roberto Senise. Manual de direito civil: obrigações e responsabilidade civil. 3. ed. São Paulo: Editora Revista dos Tribunais, 2004. v. 2.

. Responsabilidade Civil nas relações de consumo. 3. ed. São Paulo: Editora Saraiva, 2012.

MELLO, Tamila Cavaler Pessoa de. A responsabilidade civil pela perda do tempo útil: o valor social e jurídico do tempo e a sua violação como uma nova categoria de dano indenizável ao consumidor. 2013. Monografia (Graduação) - Universidade Federal de Santa Cataria, Florianópolis. 2013.

NADER, Paulo. Filosofia do direito. 15. ed. Rio de Janeiro: Forense, 2006.

PEREIRA, Claudio José Langroiva. Proteção jurídico-penal e direitos universais: tipo, tipicidade e bem jurídico universal. São Paulo: Quartier Latin, 2008.

PRADO, Luiz Regis. Bem jurídico-penal e constituição. 3. ed. São Paulo: Revista dos Tribunais, 2003.

SAVI, Sérgio. Responsabilidade civil por perda de uma chance. 2.ed. São Paulo: Atlas, 2009.

SCHREIBER, Anderson. Novos paradigmas da responsabilidade civil: da erosão dos filtros da reparação à diluição dos danos. 5. ed. São Paulo: Atlas, 2013.

SILVA, José Afonso da. Curso de direito constitucional positivo. 13. ed. São Paulo: Malheiros, 1997.

TARTUCE, Flávio. Direito civil: direito das obrigações e responsabilidade civil. 6. ed. São Paulo: Método, 2011. v. 2.

TEIXEIRA, Tarcisio. Curso de direito e processo eletrônico: doutrina, prática e jurisprudência. 2. ed. São Paulo: Saraiva, 2014. 
TEIXEIRA, Tarcisio. Direito empresarial sistematizado: doutrina, prática e jurisprudência. 4. ed. São Paulo: Saraiva, 2015.

VENOSA, Sílvio de Salvo. Direito civil. 10. ed. São Paulo: Atlas, 2010. v. 4. 
